\title{
LEI NATURAL, LEI POSITIVA E OS TUPINAMBÁS NOS ENSAIOS DE MICHEL MONTAIGNE
}

Daniel Machado Gomes

Doutor em Filosofia pelo IFCS, da UFRJ (2015). Mestre em Ciencias Juridico Civilísticas pela Universidade de Coimbra, Portugal (2003). Bacharel em Direito pela UCP (1999). Desenvolve pesquisas na área de Direitos Humanos e Filosofia do Direito, com ênfase no pensamento de Jacques Derrida. É líder do grupo de pesquisa Lei, Justiça e Direitos Humanos no qual coordena o projeto Direito à Cidade e Direitos Humanos em Petrópolis. É professor do Programa de Pós Graduação Stricto Sensu em Direito da UCP (Mestrado), atuando na linha Fundamentos da Justiça e dos Direitos Humanos. Leciona na Graduação em Direito desde 2000, tendo ministrado as disciplinas de Filosofia do Direito, Direito Civil e Metodologia da Pesquisa. Foi Coordenador Geral de Pesquisa e Publicações do Centro de Ciências Jurídicas da UCP. Atualmente é Coordenador do Núcleo de Direitos Humanos e Mediação da UCP.

\section{Resumo}

O presente artigo tem o objetivo de apresentar a visão do filósofo renascentista $\mathrm{Mi}$ chel de Montaigne sobre a lei natural e a lei positiva na obra Os Ensaios em que os tupinambás servem de recurso estilístico para o autor expor suas ideias sobre a natureza. No livro, Montaigne dedica um capítulo aos índios brasileiros para demonstrar o afastamento dos europeus em relação à lei naturais e também a impossibilidade de os civilizados acessarem racionalmente a natureza. Como consequência, Montaigne entende que a lei positiva é autorreferente, um mero produto da arte caracterizado pelo "fundamento místico da autoridade das leis", expressão que indica a inviabilidade de fundamentação transcendente para as normas jurídicas.

\section{Palavras-chave}

Lei natural; Lei positiva; Fundamento místico.

\section{Abstract}

This article aims to present the vision of the Renaissance philosopher Michel de Montaigne about natural law and positive law in the work The Essays where the Tupinambás serve as stylistic resource for the author to expose his ideas about nature. In the book, Montaigne devotes a chapter to the Brazilian Indians in order to demonstrate 
the Europeans distante in relation to natural law and also the impossibility of civilized people to access natural laws. As a result, Montaigne understands that positive law is self -referential, a mere product of art characterized by "mystical foundation of the laws authority," a term that indicates the impossibility of transcendent foundation for the laws.

\section{Key words}

Natural law; Positive law; Mystical foundation.

\section{Introdução}

No capítulo Dos Canibais, dos Ensaios Michel de Montaigne se debruça sobre os costumes dos tupinambás para indicar que os índios brasileiros estão mais próximos da lei natural do que os europeus-civilizados que a teriam perdido para sempre. Montaigne aproveitou a recém-descoberta do Novo Mundo no século XVI para questionar a cultura europeia e discutir a relaçáo entre direito positivo e direito natural. Trata-se de uma maneira peculiar de abordar a questão da fundamentação das leis, um tema que ainda hoje não encontra uma resposta apodítica dos autores. Neste sentido, é importante conhecer as contribuiçóes de Montaigne sobretudo por se tratar de um autor cujas ideias não são normalmente estudadas nos manuais de Filosofia do Direito. Assim, o presente texto apresenta uma perspectiva original sobre velhas questóes que ainda ocupam quem se dedica a investigar problemas filosóficos em torno da lei e da justiça.

Nas páginas que seguem, este texto indicará como Montaigne se posiciona em relação à oposição natureza/arte e como ele introduz o debate acerca da lei natural através de consideraçóes sobre os tupinambás. Nos Ensaios, natureza e arte se articulam inicialmente por oposição, mas depois passam a se contaminar mutuamente, levando a questão para a maior ou menor aproximação ao natural. Montaigne considerou que a natureza é dependente da arte pela necessidade de um discurso organizado pela retórica, o que torna inviável compreendermos a natureza em si. Paradoxalmente, nos Ensaios se afirma que sempre seguimos a natureza mesmo sem compreendê-la, pois Montaigne a caracteriza como a inconstância que se reflete em tudo inclusive no Direito e nas leis positivas.

Diante deste quadro que supóem a inviabilidade de conhecimento da lei natural, o artigo se encerra com a análise do fundamento místico da autoridade das leis, expressão usada por Montaigne em Da Experiência, último capítulo de seu livro, para atestar a falta de relação das normas positivas com as leis naturais. A noção de fundamento místico está entre as maiores contribuiçóes de Montaigne para a Filosofia do Direito porque questiona nossa compreensão do direito natural, delimitando o Direito no campo da arte (técnica).

Para as citações do texto original dos Ensaios, o trabalho se vale da edição de Pierre Villey, conforme o texto do exemplar de Bordeaux, ainda hoje considerada uma edição 
de referência. Nas citaçóes que estão no corpo do texto foi utilizada a tradução para o português, realizada por Rosemary Costhek Abílio, a partir da edição de Villey. A versão brasileira da obra está publicada em três volumes - um para cada livro dos Ensaios - pela editora Martins Fontes. Assim, nas citaçóes do Ensaios, deve-se considerar que o primeiro número em algarismos romanos indica o livro, o segundo número romano indica o capítulo e o terceiro número, em algarismos arábicos, aponta a página, seja da edição original francesa, seja da tradução brasileira, conforme o caso.

\section{0 Direito e os Índios Tupinambás nos Ensaios}

Nos Ensaios de Michel de Montaigne, o Direito apresenta uma dupla importância: contribui para moldar os modos de investigação do autor e também é objeto de reflexão em diversos trechos da obra. Durante anos Montaigne atuou como magistrado junto à Câmara de Inquéritos do Parlamento de Bordeaux, tendo sido relator de 44 processos nos quais ordenou informaçóes, redigiu resumos e prolatou decisôes apoiadas na jurisprudência. Mais tarde Montaigne abandonou a magistratura, aderindo à fórmula de Sêneca “Otium cum litteris' que resultou nos Ensaios, a primeira obra em língua francesa a exprimir um pensamento filosófico original, conforme aponta Hugo Friedrich (1968, p. 33). O método de elaboração dos Ensaios deve muito à experiência de Montaigne na magistratura pois o ensaio se aproxima da prolação de uma sentença judicial baseada na tradição, na letra da lei e nos comentários dos jurisconsultos, segundo os estudos do francês André Tournon (2000, p.198, 199).

No capítulo Dos Canibais, Montaigne teceu diversas consideraçóes sobre o direito natural e o direito positivo, tendo como pano de fundo a discussão sobre a adequação do canibalismo às leis naturais. Este ensaio começa com o relato da perturbadora constatação do rei grego Pirro que, ao entrar na Itália, percebe que a disposição do exército romano não era nem um pouco bárbara. Apesar de os gregos considerarem os estrangeiros bárbaros, Pirro encontra mais identificação do que diferença nos romanos. Após narrar o que ocorreu com Pirro, Montaigne passa a relatar os costumes dos selvagens brasileiros que praticam o canibalismo que gera repúdio e estranhamento aos franceses. Entretanto, assim como aconteceu com Pirro, Montaigne identifica-se mais com os tupinambás do que com os europeus, constatando que os índicos cumprem melhor o ideal de perfeição dos civilizados do que os próprios brancos. Para Montaigne, os índios se conservam na pureza original das leis naturais que nós "civilizados" perdemos para sempre, pois no estado dos tupinambás mantém-se o acesso direto às leis da natureza anterior à corrupção pela arte.

1 Sabe-se que a célebre retraite montaigniana não foi exatamente uma retirada da vida pública, mas um projeto particular com relação a esta. Além disso, o ensaísta já havia atingido aquele que talvez fosse o objetivo pessoal principal de sua função pública: consolidar sua posiçáo no seio da nobreza francesa. 
Marc Blanchard (1990, p. 111) divide as interpretaçóes sobre o capítulo Dos Canibais em dois grupos. $\mathrm{O}$ primeiro enxerga as preocupaçôes do homem moderno com a descoberta do Novo Mundo que leva ao reexame dos valores europeus. O segundo grupo entende que o ensaio se refere aos fundamentos do conhecimento e da experiência, além de reexaminar a cultura europeia. Blanchard insere na primeira corrente a obra do historiador Géralde Nakam e na segunda o trabalho de Tzvetan Todorov que entende que Montaigne utiliza os tupinambás num sentido metafórico para discutir questôes filosóficas ligadas à alteridade ${ }^{2}$, questionando os costumes europeus. A argumentação de Montaigne no capítulo sobre os índios serve para demarcar a inviabilidade epistemológica do conhecimento da lei natural por nós humanos, além de criticar nossas leis.

No começo de Dos Canibais, Montaigne faz uma reconstituição literária que idealiza o tupinambá como homem impassível, corajoso, senhor de si, aquele que não teme sequer a morte pela honra, verdadeiro sábio, um Sócrates. No entanto, ao longo do capítulo, a oposição selvagem/civilizado vai sendo corrompida pelo autor porque a interseção entre os dois termos antagônicos gera uma contaminação que resulta no "tupinambá-civilizado" e no "europeu-selvagem". A mistura entre civilização e barbárie está presente desde o início do ensaio Dos Canibais que não deve ser lido apenas como um estudo etnológico apesar de estar baseado em dados da etnografia tupinambá. Assim, Montaigne usa o tupinambá como uma imagem que traduz a impossibilidade de nós civilizados acessarmos a lei natural.

Claude Lévi-Strauss (1993, p. 192) entende que tanto a nossa cultura quanto a cultura tupinambá sã̃o incomensuráveis para Montaigne e, por isso mesmo, o ensaísta oferece ao leitor um resumo bastante documentado da etnografia tupinambá. Lévi-Strauss ressalta que Montaigne se abstém de julgar costumes e crenças tupinambás que tinham tudo para chocar almas cristãs. Montaigne não julga os costumes indígenas exceto para notar que certos usos tupinambás são menos revoltantes do que os nossos, como a crueldade das guerras de religião na França. Montaigne contrapóe estas guerras ao canibalismo e demonstra que o ato canibal expressava a valentia na guerra, superioridade em face do inimigo, sendo menos reprovável do que a tortura e extermínio em nome do cristianismo. Desta forma, Montaigne denuncia o que existe de bárbaro nos europeus civilizados e também o que há de civilizado nos tupinambás bárbaros.

Apesar de os canibais serem apresentados nos Ensaios como o reflexo mais próximo das leis da natureza, o próprio Montaigne afirma que náo viu a sociedade tupinambá e que suas observaçóes se baseiam nos relatos de uma testemunha, bem como num breve

2 Em A Descoberta da América, Todorov explorou extensamente as possibilidades de utilizar o Novo Mundo para representar a ideia de alteridade com suas mais diversas implicaçóes. Todorov (2011, p.3) busca questionar em que medida o outro é diferente do eu: "podem-se descobrir os outros em si mesmo, e perceber que não se é uma substância homogênea, e radicalmente diferente de tudo o que não é si mesmo; eu é um outro. Mas cada um dos outros é um eu também, sujeito como eu”. 
encontro com dois canibais exilados que foram traduzidos por um intérprete inconfrável. Para Terence Cave (2002, p. 302), considerando o conjunto das observaçóes sobre as quais Montaigne estrutura o seu ensaio sobre os canibais, o capítulo deve ser lido como uma instância da literatura de viagens lendárias.

De modo paradoxal com as ideias expostas inicialmente, Montaigne chega a afirmar que os índios também se encontram na ordem da arte ${ }^{3}$, já que o canibalismo assume um sentido ritual na cultura tupinambá. Deste modo, somos levados à questấo da maior ou menor aproximação à natureza pois os tupinambás não estão num plano puramente natural, confirmando que selvagens e civilizados têm mais em comum do que diferenças entre si. Desta maneira, a imagem do selvagem como um homem avant la chute em contato direto com a natureza caracteriza um expediente para estabelecer um contraponto com os europeus.

Telma Birchal (2007, p.107) explica que através dos canibais Montaigne pretende expor a barbárie presente na cultura dos europeus que passa despercebida aos olhos civilizados. Nesta mesma linha, Lévi-Strauss (1993, p. 190) lembra que Montaigne sublinha diferenças e semelhanças entre o Novo e Velho Mundo ${ }^{4}$, colocando a identidade e a contradiçáo no mesmo plano como se tanto fizesse que os costumes de povos exóticos fossem iguais ou diferentes dos nossos porque por toda parte costumes e crenças são arbitrários. Assim, em maior ou menor grau, o homem está sempre inscrito na ordem da arte por the ser interditado o acesso direto à natureza pura, e Montaigne reconhece que a ruína dos indígenas já deva estar bem avançada devido ao contato com os europeus.

O capítulo Dos Canibais usa a descoberta do Novo Mundo para denunciar nosso afastamento das leis naturais, a causa última do "fundamento místico" que aparece em $D a$ Experiência, o último capítulo dos Ensaios. Quando Montaigne afirma que as leis naturais ainda governam os canibais, ele visa demonstrar que os europeus estão completamente apartados da lei natural. No fundo, Montaigne indica que a cultura tupinambá não é táo diferente da nossa, sendo até mais civilizada em alguns aspectos, pois a cultura europeia se caracteriza por práticas bárbaras de extrema crueldade como no caso das guerras religiosas francesas 5 .

3 A respeito das divergências interpretativas sobre o sentido do capítulo Dos Canibais, ver The Cannibal Virtue, de Celso Azar Filho, publicado em Revelations of Character: Ethos, Retoric and Moral Philosophy in Montaigne. Newcastle: Cambridge Svholars Publishing, 2007.

4 Nos Ensaios o Novo Mundo é abordado de frente em três capítulos: Dos Canibais (I, XXX), Dos Coches (III, VI) e numa passagem da Apologia de Raymond Sebond (II, XII). Lévi-Strauss (1993, p. 193) considera que, de todos capítulos em que o Novo Mundo é enfocado nos Ensaios, a Apologia de Raymond Sebond é aquele em que Montaigne utiliza dados etnográficos de modo mais radical, pois nele o ensaísta não analisa costumes e crenças para legitimá-los ou relativizá-los, mas serve-se deles para instruir o processo da própria razão.

5 O tema das guerras de religiâo aparece em diversas manifestaçóes da cultura francesa renascentista. Dentre os autores daquela época que melhor retrata a situação está Aggripa D’Aubigné, conforme se lê 


\section{Arte, Natureza e Lei}

A articulação entre natureza e arte aparece inicialmente sob a forma de uma oposição em Dos Canibais pois a arte pode ser definida como o que não é natural ou aquilo que é acrescentado à natureza ${ }^{6}$. Logo a natureza tende a ser valorada positivamente ao contrário da arte, no entanto Montaigne procura demonstrar a inevitabilidade da contaminação de um termo pelo outro. Ele não se detém na mera dualidade natureza/arte já que a aproximação ao natural depende de um discurso organizado.

De acordo com André Scolarick (2008, p. 9-11), o vocábulo arte é empregado nos Ensaios com o sentido aristotélico de técnica (tékne) para indicar um saber verdadeiro de nexos universais entre causas e efeitos. Além disso, há influência da polêmica conhecida como "Querela das Artes" que se desenrolou em torno da maior dignidade do Direito ou da Medicina, no século XV. Para Scolarick (idem, p.9), Montaigne censura não apenas a pretensão de ciência do Direito, mas sobretudo o intento de constituí-lo como arte ${ }^{7}$ - grande projeto do humanismo jurídico ${ }^{8}$. Segundo Montaigne, a Ética e as condutas individuais não devem se pautar por leis universais ou prescriçóes de uma arte, mas sim pelo conhecimento de si na irredutível singularidade do sujeito. Scolarick (idem, p. 11 e 12) enxerga uma crítica às artes em Montaigne pela recusa à pretensão normativa das técnicas sobre as condutas, assinalando-se uma fronteira que separa a arte (técnica) da Ética ${ }^{9}$

na obra Les Tragiques: "Ô France désolée! Ô terre sanguinaire, Non Pas terre, mais cendre! Ô mère, si c'est mère Que trahir ses enfants aux douceurs de son sein Et quand on les meurtrit les serrer de sa main!

6 A natureza no seu estado puro manifesta o desejo divino que é sinônimo de Deus, nos indivíduos ela é o ser verdadeiro ao qual se pode chegar eliminando erros de autopercepção (Cave, 2002, p.300).

7 Michel Villey (2007, p. 30-31) aponta que na República romana, por volta da época ciceroniana, empreendeu-se conferir ao Direito a forma de "arte". A obra de Cícero De Oratore, I, 188 e ss versa sobre a formação e os conhecimentos jurídicos do bom orador. Trata-se de influência grega pois os gregos haviam criado "artes" em outras áreas, como a música, a gramática, a geometria sob a dependência de um pequeno número de princípios. Posteriormente, os humanistas franceses retomam o projeto de sistematizaçáo do direito romano - jus in artem redigere -, baseando-se na crença da racionalidade do Direito.

8 Alberto de Barros (2010 p.10-16) explica que o humanismo jurídico francês no século XVI - mos gallicus - desenvolveu um método de ensino jurídico, baseado na crítica filológica e histórica da compilação de Justiniano, cujo objetivo era restaurar o autêntico direito romano, sob a influência do projeto ciceroniano de jus in artem redigere. Buscava-se, com isso, aplicar ao Direito o esforço humanista na recuperação das artes antigas, a fim de retomar a proposta de Cícero que pretendia expor o direito romano como uma arte, ou seja, numa ordem simples e racional. O mos gallicus surgiu na esteira dos estudos que vinham sendo desenvolvidos desde o século XIV, na Itália, sob o nome de mos italicus. Foi na França que a aplicação do instrumental humanista ao Direito ganhou dimensōes de um verdadeiro movimento.

9 Scolarick (2008, p.14) aproxima a obra de Montaigne da perspectiva aristotélica, já que Aristóteles atacou de maneira incisiva a ética intelectualista socrática, sustentando no último capítulo livro VI, da Ética a Nicômaco que a virtude moral não é apenas intelectual, mas desiderativa. Assim, não basta conhecer o bem, mas é preciso desejar agir de tal modo: "É Aristóteles que ensina a Montaigne o papel do hábito e da dimensão desiderativa na formação da compleição moral dos indivíduos ... O limite desta aproximação está, certamente, na recusa montaigniana em admitir o uso de normas ou paradigmas 
e que indica, portanto, uma crítica mais geral à cultura europeia fundada na arte. Apesar disso, a natureza se revela dependente da arte aos olhos de Montaigne por necessitar de um discurso minimamente organizado pela retórica ${ }^{10}$.

Montaigne não nega que a natureza exista entretanto afirma que para nós humanos ela só aparece através da arte e, por isso, está sempre escondida, obscurecida, travestida, relegada à invisibilidade. Diante deste panorama, Montaigne buscará com seus Ensaios naturalizar a arte em lugar de artificializar a natureza já que não há saída: desde o momento do nascimento o homem está inserido em uma não-natureza. Esta ordem artificial comporta também a "arte jurídica”, o que explica o sentido autorreferente do Direito que é ditado pelo "fundamento místico da autoridade das leis" para Montaigne"

Apesar de Montaigne negar que tenhamos acesso à lei natural, ele afirma que nada é senão de acordo com a natureza e, neste sentido, não podemos escapar de seguir a natura mater: "Chamamos de contra a natureza o que acontece contra o costume: tudo que existe está de acordo com ela, o que quer que seja"12 (Ensaios, II, 30, p.570). Com isso, os Ensaios indicam uma divisão entre seguir a natureza e conhecê-la pois, mesmo se quiséssemos, não poderíamos desobedecer ao preceito soberano que estabelece a obediência à mãe natureza, conforme se lê na seguinte passagem: "Como disse alhures, no que me concerne adotei muito simples e cruamente este preceito antigo: que não poderíamos errar seguindo a natureza, que o preceito soberano é conformar-se a ela" (Ensaios, III, 12, p.413) ${ }^{13}$.

Montaigne afirma que tudo é de acordo com a natureza, pois a natureza indica o próprio devir, o branloire inevitável, o movimento do qual não se pode escapar. Neste sentido, Azar Filho (1996, p.53) explica que nos Ensaios a natureza implica num princípio de criação, movimento e diversificação tanto dos seres singulares, quanto da economia do todo $^{14}$. Trata-se da "natura creatrix, variável, mutante e inventiva que sobrepassa qualquer

morais exteriores à própria constituição do sujeito - à exceção daquelas que lhe impóem condutas no registro público" (Scolarick, 2008, p.16).

10 Um exemplo disso nos Ensaios é o capítulo De l'institution des enfants, no qual a criança é vista como o mais puramente natural dos fenômenos, mas também como algo incompreensível. Neste mesmo capítulo, Montaigne demonstra que, diferentemente dos animais, as crianças se utilizam das convençōes sociais desde o início, inclusive mentindo. Neste sentido, a criança encarna o paradoxo do natural e do artificial, ao mesmo tempo.

11 Todo o Direito padece deste mesmo problema, apesar de as leis mais novas serem mais artificiais e mais reprováveis aos olhos do ensaísta, razão pela qual no capítulo De la Vanité ele revela que prefere regras baseadas em costumes antigos aos esquemas legais utópicos que se mostram meros produtos da arte.

12 "Nous apelons contre nature ce qui advient contre la coustume: rien n'est que selon elle, quel qu'il soit" (Essais, II, 30, p. 713).

13 "J'ay pris, comme j'ay dict ailleurs, bien simplement et cruement pour mon regard ce precepte ancien: que nous ne sçaurions faillir à suivre nature, que le souverain precepte c'est de se conformer à elle" (Essais, III, $12 \mathrm{p}$. 1059).

14 No texto Natureza e Lei Natural nos Ensaios de Montaigne, Celso Azar Filho (1996, p.54) explica que este vivere secundum naturam é próprio do Renascimento, uma vez que retoma o saber antigo da época 
enquadramento teórico" (Azar Filho, idem, p.52). Para além do próprio movimento, a natureza compreende um devir constante que conduz ao inesperado, ao inusitado, à fortuna (na linguagem renascentista) e à morte.

A natureza se conforma com o curso para a morte que seguimos mesmo a contragosto ou sem compreendermos. A morte é o tempo cíclico do que é natural pois está em toda a natureza. Lúcio Vaz (2011, p. 101) explica que a filosofia ensaística insere a morte na natureza com o intuito de dissipar o medo do nosso próprio fim. Montaigne associa a marcha ordinária da natureza com um caminho para a morte tal qual ocorre com as couves:

"Se a natureza encerra nos termos de seu andamento habitual, como todas as outras coisas, também as crenças, os juízos e as opiniốes dos homens; se eles têm sua revolução, sua estação, seu nascimento, sua morte como repolhos; se o céu os agita e gira à vontade, que autoridade magistral e permanente lhes atribuiremos?"15 (Ensaios, II, 12, p. 364).

Montaigne entende que nada se dá em permanência por natureza, tudo está se encaminhando para a morte. Ele constata a inerência da morte na vida, demonstrando que nosso primeiro dia já nos encaminha para viver e para morrer: "Todos os dias caminham para a morte; o último chega a ela" ${ }^{16}$ (Ensaios, I, 20, p.140). Na cadeia inexplicável do porvir, a morte aparece como o último ato do fluxo sucessivo de movimentos, e este ato final impulsiona a razão a ordenar a vida e estabelecer algum sentido perante o inexplicável.

Thomas Berns (2000, p. 280) explica que a inconstância da natureza se reflete também na inconstância das leis positivas pois a ausência de contato com a natureza constante e permanente leva Montaigne a integrar no Direito o que deveria ser o seu fundamento. Dessa maneira, aniquila-se qualquer hipótese de referência a um direito natural imutável, externo às leis, o fundamento das normas se torna exclusivamente histórico, relativo e inconstante. Diante da inconstância da natureza, só resta ao Direito o fundamento "místico" que explica a contingência das leis positivas que se sucedem continuamente no tempo.

helenística que prescrevia subordinação à medida natural. Assim, nos Ensaios está consignado que todo homem segue impreterivelmente a natura mater, apesar de não compreender o sentido da natureza nem das leis naturais. Dessa maneira, Montaigne vincula o problema do conhecimento da natureza ao mal uso da razão, já que para ele não há nada que não seja bom e regrado, mas nós humanos não enxergamos a harmonia nem a relação das coisas. Para Montaigne, os filósofos nos reenviam às regras da natureza, mas eles não têm o conhecimento do que propõem e acabam por falsificá-la, apresentando-a pintada e sofisticada.

15 "Si la nature enserre dans le termes de son progrez ordinaire, comme toutes autres choses, aussi les creances, les jugements et opinions des hommes; si eles ont leur revolution, leur saison, leur naissance, leur mort, comme les chous...quelle magistrale authorité et permanente leur allons nous attribuant?” (Essais, II, XII, p.575).

16 “Tous les jours vont à la mort, le dernier y arrive” (Essais, I, 20, p.96). 
Para Berns (idem, p. 279), Montaigne encara o tempo como sendo fundamentalmente descontínuo e inscrito numa insuperável particularidade de cada instante ${ }^{17}$. $\mathrm{O}$ autor explica que a temporalidade náo corresponde a um processo orientado mas a um salto de instante a instante num horizonte de descontinuidade. Neste quadro, o ser se opóe ao tempo, interditando o acesso à "Lei Natural" e promovendo as leis. A diversidade de normas, interpretaçóes e casos não permite apreender a lei natural mas a apaga. Leis naturais imutáveis e constantes são um artifício imaginário, um mero discurso, conforme Montaigne indica na Apologia de Sebond:

"Mas eles são engraçados quando, para dar às leis alguma autenticidade, dizem que há algumas sólidas, perpétuas e imutáveis, que chamam de naturais, que estão impressas no gênero humano pela condição de sua

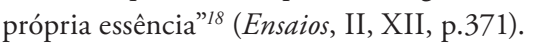

A falta de um fundamento externo à legalidade transforma a noção de legitimidade jurídica em uma ficção de maneira que Montaigne chega a comparar a lei à moeda falsa cujo valor está baseado na confiança e não em atributos externos ou internos. Assim, a moeda falsa vale tanto quanto a verdadeira desde que se confie na sua veracidade, como se lê nos Ensaios:

"Posto que os homens, por sua insuficiência, não conseguem pagar-se com uma moeda verdadeira, que se continue a empregar a falsa. Esse expediente foi praticado por todos os legisladores, e não existe sociedade em que não haja alguma mescla ou de cerimônia vã ou de ideia mentirosa que sirva de rédea para manter o povo no dever. É por isso que a maioria tem suas origens e inícios fabulosos enriquecidos de mistérios sobrenaturais"19 (Ensaios, II, 16, p.445).

O caráter ficcional da legitimidade jurídica aponta para a origem precária da lei, a "mística" do Direito. A precariedade deste começo se inscreve numa temporalidade descontinua e fragmentada que leva Montaigne a defender a maior permanência possível de uma mesma lei em vigor. Só esta vigência duradoura pode suprir o déficit de legitimidade

17 Berns comenta a noção de tempo nos Ensaios, quando discute questôes relativas à História. Ele fundamenta seus comentários em uma passagem do fim da Apologia: "Mas entâo o que existe verdadeiramente? O que é eterno, isto é, que nunca teve nascimento e nunca terá fim; para o qual o tempo não traz mutação alguma. Pois o tempo é coisa mutável...” (Ensaios, II, XII, p. 405 - edição Villey: p. 603)

18 "Mais ils sont plaisans quando, pour donner quelque certitude aux loix, ils disent qu' il y em a aucunes fermes, perpetuelles et immuables, qu'ils nomment naturelles, qui sont empreintes em l'humain genre par la condition de leur propre essence" (Essais, II, 12 p. 579-80).

19 "Puis que les hommes, par leur insuffisance, ne se peuvent assez payer d'une bonne monnoye, qu'on y employe encore la fauce. Ce moyen a esté practiqué par tous les Legislateurs, et n'est police où il n'y ait quelque meslange ou de vanité ceremonieuse ou d'opinion mesongere, qui serve de bride à tenir le peuple en office. C'est pour cela que la pluspart ont leurs origines et commencemens fabuleux et enrichis de mysteres supernaturels" (Essais, II, 16, p.629). 
das leis e fazer frente à nossa inconstância natural (Essais, II, 12, p.518). Por fim, é possível perceber que um conjunto de premissas como arte, inconstância, temporalidade e fortuna levam Montaigne a entender o Direito restrito à ordem da arte, sendo este o fundamento místico da lei.

\section{Lei Natural e Interdição}

Montaigne afirma que em nós humanos as leis naturais se perderam para sempre, supondo a inviabilidade de acessarmos a lei natural. Logo é insensato empreender uma busca para encontrar o direito natural já que esta iniciativa consiste numa arqueologia impossível aos olhos de Montaigne ${ }^{20}$. No ensaio Apologia de Raymond Sebond Montaigne reafirma que não existe acesso às leis naturais:

"É de crer que haja leis naturais, como se veem nas outras criaturas; mas em nós elas estão perdidas, como essa bela razão humana intrometendose em toda parte para dominar e comandar, embaralhando e confundindo a face das coisas segundo sua vaidade e inconstância”21 (Ensaios, II, 12, p. 372).

O fato de as leis naturais se perderem em nós não significa que elas se perderam em si. O problema se situa na esfera epistemológica porque retorna à questão da interdição a qualquer forma ideal já que a razão tudo confunde, turva a face das coisas segundo a própria vaidade e inconstância. Na ótica ensaística, o mal uso da razão humana gerou uma cisão tamanha entre a natureza e o homem, que nos interditou o acesso às leis naturais. É possível que estas leis existam mas, para nós, elas se perderam por causa da razão que artificializou toda a existência com a arte (técnica). Inviabilizou-se qualquer contato direto com a natureza e com as suas leis, não restando nada que seja verdadeiramente nosso. Tudo é produção da arte conforme a passagem de Cícero recolhida nos Ensaios: "Nibil itaque amplius nostrum est: quod nostrum dico, artis est" (Essais, II, 12, p.580) ${ }^{22}$.

20 Na obra Direito Natural e História, Leo Strauss (2009, p. 159) afirma que Montaigne integra a corrente convencionalista, segundo a qual, a sociedade é convencional ou artificial, o que implica na sua desvalorizaçáo. De acordo com Strauss, Montaigne identifica a vida conforme à natureza com a vida que antecede a sociedade civil, considerando preferível o "estado natural" do homem. Strauss (idem, p. 84) discorre sobre os convencionalistas, afirmando que eles tradicionalmente advogam a impossibilidade do direito natural, sob o argumento de que as coisas justas variam de sociedade para sociedade. $\mathrm{O}$ autor alemáo indica que o cerne do convencionalismo está na ideia de que o Direito resulta por essência da cidade e que esta é sempre convencional (ibidem 93).

21 "Il est croyable qu'ily a des loix naturelles, comme il se voit és autres creatures; mais en nous elles sont perdues, cette belle raison humaine s'ingerant par tout de maistriser et commander, brouillant et confondant le visage des choses selon sa vanité et inconstance" (Essais, II, 12, p.580).

22 "Nada resta que seja verdadeiramente nosso: o que chamo de nosso não passa de uma produçấo da arte" (Cícero, Den fin., V, XXI) Trad. de Rosemary Costhek Abílio. Ensaios, II, p. 372. 
Dessa maneira, Montaigne considera que os objetos se apresentam para nós sempre em relação e nunca em si mesmos. Nada se nos apresenta em essência, in natura, tampouco a lei. O homem se torna dependente do artifício do discurso e da artificialidade da linguagem, a dicotomia entre lei natural e lei positiva se dilui neste quadro que reveste os objetos do pensamento. A lex humana se mistura à lex naturalis de modo a formarem uma única res. Ambas só se apresentam na forma discursiva e são produtos do discurso ${ }^{23}$.

O esforço de delimitar um campo normativo para o direito natural e relacioná-lo com o direito positivo configura um empreendimento literário. Toda empreitada de fundamentar as normas positivas em uma lei natural resulta num desfecho tautológico e cíclico que parte da linguagem para retornar à própria linguagem. Este aprisionamento ao discurso coloca a lei natural e a lei positiva em um mesmo plano que impede uma relação de fundamentação entre elas, levando Montaigne ao fundamento místico da autoridade das leis ${ }^{24}$.

No ensaio Da Experiência, Montaigne se refere ao "fundamento místico" para atestar a falta de relação das normas positivas com as leis naturais que delimita o Direito no campo da arte (técnica). Com isso, subjaz aos Ensaios uma cisão entre o justo e o jurídico que serve para demonstrar que o Direito é uma realidade construída politicamente. Montaigne enxerga uma inviabilidade instransponível de qualquer forma de fundamentação transcendente para a lei porque o fundamento místico é uma barreira que delimita as normas na legalidade estrita. A lei vale simplesmente por ser lei, sendo impossível justificá-la com base em conceitos metafísicos como a lei natural. Para evidenciar a autorreferência do campo jurídico, Montaigne explica: "Ora, as leis conservam seu prestígio não por serem justas mas porque são leis. Esse é o fundamento místico de sua autoridade e não têm

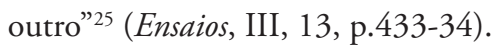

Ana Maria Continentino (2004, p. 142) entende que o "fundamento místico da lei" indica um esquecimento necessário da força instauradora do Direito, da origem violenta da lei. Segundo Thomas Berns (2000, p. 393), este esquecimento se erige como condição de aplicabilidade da própria lei, pois Montaigne considera perigoso lembrar da origem das normas devido ao seu início sempre precário e arbitrário: "As leis extraem da aplicação e do uso sua autoridade; é perigoso levá-las de volta ao seu nascimento..."26 (Ensaios, II,

23 Estas conclusóes, que podem ser legitimamente inferidas do texto de Montaigne, se coadunam com o pensamento desconstrucionista do Direito, na perspectiva derridiana. Em última análise são desdobramentos da noção de "fundamento místico", que reforçam a apreciaçáo de Derrida sobre o sentido desta expressão criada por Montaigne.

24 A ideia montaigniana da existência de um "fundamento místico da lei" influenciou toda uma linha de interpretação sobre a legalidade que se caracterizou pelo viés crítico, ampliando e aprofundando as reflexôes presentes nos Ensaios. É o caso de Pascal, Montesquieu, Niezsche e Derrida.

25 "Or les loix se maintiennent en credit, non par ce qu'elles sont justes, mais parce qu'elles sont loix. C'est le fondement mystique de leur authorité; eles n'en ont poinct d'autre" (Essais, III, 13, p. 1072).

26 "Les loix prennent leur authorité de la possession et de l'usage, il est dangereux de se ramener à leur naissance..." (Essais, II, 12, p.583). 
12, p. 376). Deste modo, na perspectiva ensaística o começo das leis não está à altura da sua pretensa autoridade, fato que sempre pode suscitar a contestação da ordem jurídica. O fundamento místico serve, portanto, para desmistificar a autoridade da lei.

Montaigne aproveita a carga simbólica de mistério inefável implícita no adjetivo "místico" para sinalizar que não há como discorrer sobre qualquer fundamento metafísico no Direito. Isso confere ao direito positivo um caráter autorreferenciado, ressaltando o sentido meramente histórico e precário da origem da lei que Montaigne considera a gênese do Direito. Montaigne identifica a historicidade com a simples causalidade que afasta qualquer pretensão de fundamentos racionais (Berns, ibidem, p. 273). Consequentemente as leis se pautam mais na fortuna do que na razão, devido à origem arbitrária da autoridade, de acordo com os Ensaios:

"Abismado com importância do empreendimento, outrora fiquei sabendo de seus motivos e sua tática, pelos que o levaram a cabo; só lhes encontrei ideias banais; e as mais banais e usuais talvez sejam também as mais seguras e mais vantajosas para a execução, se não para a exibição" ${ }^{27}$ (Ensaios, III, 8, p. 222).

Neste quadro dominado pelo acaso, a lei nasce fortuitamente para ser aplicada pelo julgador de modo igualmente fortuito já que em torno da lei tudo remete a opinióes e paixóes, a arbitrariedade determina nossa obediência à lei pelo simples fato de ser lei:

"O que nos dirá então nessa contingência então a filosofia? Que sigamos as leis de nosso país? Ou seja, esse mar flutuante das opinióes de um povo ou de um príncipe, que me pintarão a justiça com tantas cores e a reformarão em tantas faces quantas mudanças de paixão houver neles? ... Qual bondade é essa que ontem eu via valorizada e amanhã não mais, (se) e que a travessia de um rio torna crime?”28 (Ensaios, II, 12, p. 370-371).

O fundamento místico da autoridade das leis consiste em desmistificar a fundamentação do Direito e circunscrevê-lo à legalidade estrita sem qualquer fundamento transcendente. Com isso, o Direito se revela circular e tautológico, o conhecimento da lei natural se mostra impossível e a nossa relação com a natureza aparece contaminada pela arte. A consciência da inviabilidade de conhecimento da natureza é o ponto de partida para os Ensaios discorrerem sobre a legalidade. Neste sentido, os tupinambás atuam como um

27 "Éstonné de la grandeur de l'affaire, j'ay autrefois sceu par ceux qui l'avoient mené à fin leurs motifs et leur adresse: je n'y ay trouvé que des advis vulgaires; et les plus vulgaires et usitez sont aussi peut estre les plus seurs et plus commodes à la pratique, sinon à la montre." (Essais, III, 8, p.933)

28 "Que nous dira donc en cette necessité la philosophie? Ques nous suyvons les loix de nostre pays? C'est à dire cette mer flotante des opinions d'un peuple ou d'un Prince, qui me peindront la justice d'autant de couleurs et la reformeront em autant de visages qu'il y aura em eux de changements de passion?... Quelle bonté est-ce que je voyois hyer em credit, et demain plus, et que le trajet d'une riviere faict crime?”(Essais, II, 12, p. 579). 
recurso para Montaigne expor seu entendimento sobre o Direito e a lei natural, articulando o fundamento místico da autoridade das leis com a questão da arte (técnica) versus natureza.

\section{Conclusões}

No decorrer deste estudo, foram apresentadas as ideias do filósofo renascentista Michel de Montaigne sobre a lei natural que aparecem na obra Os Ensaios. Montaigne trata do tema através de um recurso estilístico original: a narração dos costumes canibais dos índios tupinambás brasileiros. Os selvagens tupinambás servem de artifício literário para o ensaísta indicar a falta de acesso racional dos civilizados às leis naturais, já que Montaigne considerava que em nós humanos estas leis se perderam. Consequentemente, a inviabilidade de conhecimento do direito natural se traduz na impossibilidade de fundamentação das leis positivas que adquirem um sentido autorreferente: o fundamento místico da autoridade das leis.

$\mathrm{Na}$ primeira parte do artigo ficou demonstrado que os índios brasileiros tupinambás foram um artifício para Montaigne discutir a oposição natureza/arte e introduzir o debate acerca da lei natural. O autor se valeu da descoberta do Novo Mundo no século XVI para questionar a cultura europeia, suas instituiçóes, o direito positivo e o direito natural. Montaigne afirmou que os canibais estão mais próximos da lei natural do que os europeus-civilizados mas ele próprio reconheceu que os índios também estavam na ordem da arte, donde, a questão se deslocou em relação a uma maior ou menor aproximação à natureza.

Nos Ensaios, o homem branco e sua cultura são considerados totalmente apartados da natureza e, como consequência, o direito positivo não tem relação com o direito natural. Esta questão encaminhou o texto à análise da articulação entre natureza e arte que é apresentada inicialmente como oposição e depois como contaminação nos Ensaios. Montaigne considerou que a natureza depende de um discurso organizado pela retórica, deste modo ficou consignada a impossibilidade de compreendermos a natureza em si, apesar de Montaigne afirmar que sempre seguimos a natureza mesmo sem compreendê-la. Nos Ensaios, a natureza é entendida como a inconstância que se reflete em tudo inclusive nas leis positivas sempre variáveis no espaço e no tempo.

A inviabilidade epistemológica em relação à natureza e à lei natural encaminhou o artigo para a análise do fundamento mistico da autoridade das leis, expressão usada por Montaigne para atestar a falta de relação das normas positivas com as leis naturais. $\mathrm{O}$ fundamento místico é considerado uma das maiores contribuiçóes de Montaigne para a Filosofia do Direito porque delimita as leis positivas no campo da arte (técnica) e amplia discussóes que envolvem a natureza e a lei humana. Deste modo, o estudo 
sobre fundamento místico permitiu a discussão do problema da origem das normas que Montaigne considerava precária e arbitrária, determinando nossa obediência à lei pelo simples fato de ser lei e não por ser justa. Toda argumentação montaigniana leva ao caráter ficcional da legitimidade jurídica.

É possível concluir que nos Ensaios o Direito é considerado como produto da arte jurídica sem relação com a lei natural que se perdeu em nós para sempre, segundo Montaigne. O capítulo Dos Canibais adquire grande importância na compreensão do pensamento de Montaigne sobre o Direito porque usa os tupinambás brasileiros como meio literário para atestar nossa falta de acesso racional à natureza e à lei natural. Desta forma, Montaigne articula sua crítica às artes, o sentido de natureza e o fundamento místico da autoridade das leis.

\section{Referências}

\section{Fontes Primárias:}

MONTAIGNE, Michel. Les Essais. Ed. Pierre Villey, V.-L. Saulnier. Paris: PUF, 2004 (col. Quadrige).

. Os Ensaios: Livros I, II e III. Trad. de Rosemary Costhek Abílio. São Paulo: Martins Fontes, 2009.

\section{Fontes Secundárias:}

AZAR FILHO, Celso Martins. Natureza e Lei Natural nos Ensaios de Montaigne. Principios (UFRN. Impresso), Natal, v. 4, p. 51-71, 1996.

BARROS, Alberto Ribeiro G. de. Humanismo Jurídico. O que nos faz pensar. Rio de Janeiro. N. 27, p. 09-26, maio de 2010.

BERNS, Thomas. Violence de Loi à la Renaissance: L'Origine du Politique chez Machiavel et Montaigne. Paris: Kimé, 2000.

BIRCHAL, Telma de Souza. O Eu nos Ensaios de Montaigne. Belo Horizonte: UFMG, 2007.

BLANCHARD, Marc E. Trois Portraits de Montaigne: Essai sur la Représentation à la Renaissance. Paris: A.-G. Nizet, 1990.

CAVE, Terence. The Cornucopian Text: Problems of Writing in the French Renaissance. New York: Oxford University, 2002.

CONTINENTINO, Ana Maria. Horizonte Dissimétrico: Onde se Desenha a Ética Radical da Desconstrução. In: Desconstrução e Ética: Ecos de Jacques Derrida. Rio de Janeiro: PUC, 2004. 
EVA, Luiz. A Figura do Filósofo: Ceticismo e Subjetividade em Montaigne. São Paulo: Loyola, 2007.

FRIEDRICH, Hugo. Montaigne. Trad. Robert Rovini. Paris: Gallimard, 1968. (Bibliothèque des Idées).

. Humanismo Occidental. Trad. Rafael Girardot. Buenos Aires: Editorial Sur, 1973.

SCOLARICK, André. Experiência e Moralidade no Último dos Ensaios de Montaigne. São Paulo, 2008. Dissertação. (Mestrado em Filosofia) - Faculdade de Filosofia, Letras e Ciências Humanas. Universidade de São Paulo.

STAROBINSKI, Jean. Montaigne em Movimento. Trad. Maria Lúcia Machado. São Paulo: Companhia das Letras, 1992.

STRAUSS, Leo. Direito Natural e História. Trad. Miguel Morgado. Lisboa: Ediçóes 70, 2009.

TODOROV, Tzvetan. O Jardim Imperfeito: O Pensamento Humanista na França. Trad. De Mary de Barros. São Paulo: USP, 2005.

. A Conquista da América. Trad. De Beatriz Perrone-Moisés. São Paulo: Martins Fontes, 2011.

TOURNON, André. Montaigne: La Glose et L'Essai. Paris: Honoré Champion Éditeur, 2000.

. Justice Oblige. Bulletin de la Societé des Amis de Montaigne. 8, n. 21-22, p. 71-79, Jan/Jun 2001.

. Montaigne. Trad. de Edson Querubini. São Paulo: Discurso Editorial, 2004.

VILLEY, Michel. O Direito e os Direitos Humanos. Trad. de Maria Ermantina de A. P. Galvão. São Paulo: Martins Fontes, 2007. 